\title{
Research on the Impact of Overseas Investment on Corporate Social Responsibility of Listed Textile and Garment Enterprises
}

\author{
Ya Wang ${ }^{1,}$ Jiawen Peng ${ }^{2,}$ Jingyi Mai ${ }^{3,}$ Lei $\mathrm{Yao}^{4, *}$
}

\author{
${ }^{1}$ Beijing Institute of Fashion Technology, Beijing, 100029, China \\ ${ }^{2}$ Beijing Institute of Fashion Technology, Beijing, 100029, China \\ ${ }^{3}$ Beijing Institute of Fashion Technology, Beijing, 100029, China \\ ${ }^{4}$ Beijing Institute of Fashion Technology, Beijing, 100029, China \\ ${ }^{*}$ Corresponding author. Email: sxyyl@bift.edu.cn
}

\begin{abstract}
In the context of economic globalization and the Belt and Road Initiative, it is of great significance to explore the factors that influence textile and garment enterprises, which are an important part of China's enterprise organization, to fulfill their social responsibilities, for the sustainable development of economy and society. Based on the data of 82 textiles and garment enterprises listed in Shanghai and Shenzhen A-share markets from 2016 to 2019, this paper uses a balanced panel data model to explore the impact of overseas investment on corporate social responsibility. Research shows that overseas investment will promote the fulfillment of social responsibility by textile and textile enterprises, while the scale and growth of enterprises also have a boosting effect on social responsibility. Textile and garment enterprises should promote the fulfillment of shared responsibility through overseas investment and expansion of enterprise scale, so as to achieve sustainable development.
\end{abstract}

Keywords: Overseas investment, Listed textile and garment enterprises, Corporate social responsibility.

\section{INTRODUCTION}

In the context of economic globalization, overseas investment is a necessary way for enterprises to "go global" and enhance their international influence. Data show that the continuous expansion of overseas investment scale of Chinese enterprises has significantly enhanced the international competitiveness of enterprises and promoted economic growth. In the process of enterprise development, social responsibility means that enterprises not only aim at maximizing shareholders' interests, but also seek benefits for every member of social interests to the maximum extent (Yang Liying, 2020). The fulfillment of corporate social responsibility will drive the growth of corporate market value (Deng Xiuyuan et al., 2018), and at the same time will promote the sustainable development of enterprises in terms of improving the success rate of overseas mergers and acquisitions (Zhang Xuan et al., 2019). It is of great significance to explore the factors that influence textile and garment enterprises, which are an important part of economy, to fulfill their social responsibilities, for the sustainable development of enterprises and even the industry.

Studies have shown that the factors affecting corporate social responsibility are broadly divided into two aspects: endogenous motivation and external assistance. From within the enterprise, various financing structure indicators of the enterprise have certain influence on corporate social responsibility. For example, the debt ratio of listed enterprises shows an inverse relationship with their social responsibility (Cheng Yao, 2015). Taking whether managers have research experience as a dummy variable, it is concluded that the research experience of managers influences enterprise decision making and thus contributes to corporate social responsibility, especially in highly polluting industries (Wu Weixing, 2020). 
Meanwhile, corporate social responsibility report, social responsibility deficiency and financial performance are correlated, and the quality of internal control has a significant positive effect on financial performance, and has a positive moderating effect on the relationship between the quality of information disclosure of corporate social responsibility report and financial performance results (Zhong Peng et al., 2021).

With regard to external assistance, overseas investment has a significant and dynamic impact on corporate social responsibility; overseas investment significantly enhances corporate social responsibility, while host country heterogeneity and enterprise heterogeneity influence the effect of overseas investment on social responsibility (Wang Quanjing, 2018). Various macroeconomic factors have a certain degree of impact on the fulfillment of corporate social responsibility (Sun Dongmei, 2018), and the legal institutional distance, economic institutional distance and cultural institutional distance all can facilitate social responsibility of overseas investment enterprises (Song Lin et al., 2019).

At present, most of the existing researches on the impact of corporate social responsibility do not distinguish between industries. This paper subdivides the research objects into textile and garment enterprises, and adopts empirical analysis methods, focusing on the impact of overseas investment, enterprise scale and enterprise growth on corporate social responsibility.

\section{DATA DESCRIPTION AND PROCESSING}

This paper selects textile and garment enterprises listed in Shanghai and Shenzhen A-share markets as objects, and takes information such as enterprise name and stock code comes from the website of AskCI Consulting Co., Ltd., inquires about the corporate social responsibility (CSR) of textile and garment enterprises from 2016 to 2019 on Hexun.com, queries annual reports of enterprises from Qcc.com and GTAFE database to obtain the data of whether the listed textile and garment enterprises made overseas investment from 2016 to 2019, and the gross asset value and net profit growth rate each year. Among them, the total score of corporate social responsibility of listed enterprises is a comprehensive data, and the professional evaluation system of social responsibility report of listed enterprises includes five aspects: shareholder responsibility, employee responsibility, rights and interests of suppliers, clients and customers, environmental responsibility and social responsibility. Normally, shareholders' responsibility weight accounts for $30 \%$, employees' responsibility weight accounts for $15 \%$, suppliers, clients and consumers' rights responsibility weight accounts for $15 \%$, environmental responsibility weight accounts for $20 \%$, and social responsibility weight accounts for $20 \%$. The total score of the enterprise is obtained by comprehensively calculating and adding together all the weights.

The original data are processed as follows: (1) Use the CPI based on 2015 to eliminate inflation of the gross asset value; (2) Deal with the dummy variable, and determine the value of dummy variable according to whether the enterprise has made investment or bought the equity of other companies according to the annual report of the enterprise, and then judge whether there is overseas investment through the information of investment in foreign countries. In order to avoid abnormal values, this paper investigates the enterprises with abnormal financial situation, delisting risk and deficiency of relevant data, and finally selects 82 listed textile and garment enterprises, with a total of 1312 observed values, and uses the balanced panel data model for quantitative analysis.

Table1 Full Sample Descriptive Statistics

\begin{tabular}{|c|c|c|c|c|c|c|}
\hline $\begin{array}{l}\text { Indicat } \\
\text { ors }\end{array}$ & $\begin{array}{l}\text { Averag } \\
\mathrm{e}\end{array}$ & $\begin{array}{l}\text { Maxim } \\
\text { um } \\
\text { value }\end{array}$ & $\begin{array}{l}\text { Minim } \\
\text { um } \\
\text { value }\end{array}$ & $\begin{array}{l}\text { Medi } \\
\text { an }\end{array}$ & $\begin{array}{l}\text { Varia } \\
\text { nce }\end{array}$ & $\begin{array}{l}\text { Standa } \\
\text { rd } \\
\text { deviati } \\
\text { on }\end{array}$ \\
\hline
\end{tabular}

CSR

(corporate

social

22. 82.16

$16-6.36$

$23.1 \quad 153.8$

12.41

ty)

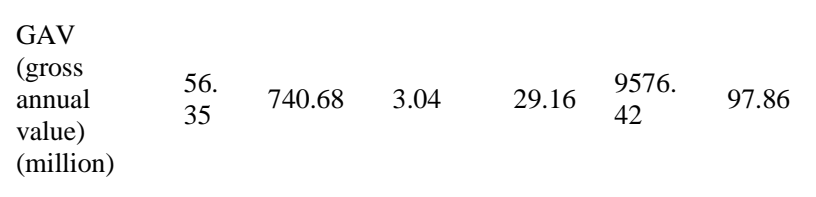

\begin{tabular}{lllllll}
$\begin{array}{l}\text { G } \\
\text { profit }\end{array}$ & - & & & & & \\
growth & 0.4 & 34.44 & -63.20 & 0.08 & 44.39 & 6.66 \\
rate) & 9 & & & & & \\
\hline
\end{tabular}

Statistical analysis of sample data shows that the maximum score of corporate social responsibility from 2016 to 2019 is 82.16 , the minimum score is -6.36 , the average value is 22.76 , and the standard deviation is 12.41 , indicating that there is a significant difference in the level of social responsibility of textile and garment enterprises, and the total score of social responsibility of textile and garment enterprises having made investment overseas is higher than that of enterprises without investment overseas. Analyzing in a longitudinal viewpoint, the total score of social responsibility of a single enterprise in the year with overseas investment is higher than that in the year without overseas investment. It is preliminarily confirmed that there are significant differences in the level of corporate social responsibility of listed textile and garment enterprises in China, and overseas investment has a positive impact on corporate social responsibility. 


\section{THEORETICAL ASSUMPTION}

\subsection{Variable selection}

The textile and garment enterprises listed in Shanghai and Shenzhen A-share markets in China are selected as research samples, and their annual reports and total score data of social responsibility from 2016 to 2019 are taken for research.

Table 2. Variable Definition

\begin{tabular}{llll}
\hline $\begin{array}{l}\text { Variable } \\
\text { type }\end{array}$ & Variable name & $\begin{array}{l}\text { Variable } \\
\text { symbol }\end{array}$ & Relative meaning \\
\hline $\begin{array}{l}\text { Explained } \\
\text { variable }\end{array}$ & $\begin{array}{l}\text { Total score of } \\
\text { corporate social } \\
\text { responsibility }\end{array}$ & CSR & $\begin{array}{l}\text { Reflect the } \\
\text { fulfillment of } \\
\text { corporate social } \\
\text { responsibility }\end{array}$ \\
\hline $\begin{array}{l}\text { Explanatory } \\
\text { variable }\end{array}$ & $\begin{array}{l}\text { Whether to } \\
\text { invest overseas }\end{array}$ & Oversea & $\begin{array}{l}\text { Reflect whether } \\
\text { the enterprise has } \\
\text { overseas } \\
\text { investments }\end{array}$ \\
\hline $\begin{array}{l}\text { Control } \\
\text { variable }\end{array}$ & $\begin{array}{l}\text { Gross asset } \\
\text { value }\end{array}$ & GAV & $\begin{array}{l}\text { Reflect the scale of } \\
\text { the enterprise }\end{array}$ \\
\cline { 2 - 4 } & growth rate & G & $\begin{array}{l}\text { Reflect the growth } \\
\text { of enterprises }\end{array}$ \\
\hline
\end{tabular}

This paper selects the total score of corporate social responsibility (CSR) as the explained variable, whether to invest overseas or not as the core explanatory variable, and the gross asset value at the end of the period (GAV) and net profit growth rate $(\mathrm{G})$ are the control variables.

\subsection{Hypothetical description}

The theoretical assumption of this paper is based on the eclectic theory of international production and the theory of comparative advantage theory in the international investment theory. The relatively transparent combination of ownership advantage, internalization advantage and location advantage enable enterprises to improve their profitability by engaging in international economic activities, expand their scale to improve their competitiveness, and provide more stable internal and external power for the fulfillment of corporate social responsibility.

The existing research assumes that corporate social responsibility has an endogenous effect on corporate performance, and is affected by company size, assets and ownership structure (He Yiqing et al., 2018). There is a significant positive correlation between the level of corporate social responsibility and sustainable profitability, that is, a high level of social responsibility can promote the long-term and stable development of enterprises (Guo Ying et al., 2018). Overseas investment by China's textile and garment enterprises focuses on Hong Kong, the Philippines and other regions with comparative advantages in technology or labor force, so as to improve the net profit of enterprises and provide more funds and experience for the fulfillment of corporate social responsibility.
Based on this, this paper puts forward the following assumptions:

H1: Overseas investment has a positive effect on corporate social responsibility.

$\mathrm{H} 2$ : Enterprise scale has a positive effect on corporate social responsibility.

H3: Enterprise growth has a positive effect on corporate social responsibility.

\section{MODEL ESTIMATION AND RESULT ANALYSIS}

According to the influence of overseas investment, the gross asset value and the growth rate of net profit on social responsibility, a multivariate linear model is established:

CSR $=C+\alpha *$ Oversea $+\beta * \mathrm{GAV}+\gamma * \mathrm{G}+u$

Among them, CSR is corporate social responsibility, Oversea means whether to invest overseas or not, GAV is the gross asset value and $\mathrm{G}$ is net profit growth rate.

The best fitting result is random effect model (4):

$$
\begin{aligned}
& C S R=21.6237+2.3573 * \text { Overse }+0.0131 * \mathrm{GAV}+ \\
& 0.0033 * \mathrm{G}+\varepsilon
\end{aligned}
$$

Regression results show that overseas investment, gross asset value and net profit growth rate has passed the significance test under the confidence of $5 \%$. The adjusted $\mathrm{R}^{2}$ value of the model is $0.0831, \mathrm{~F}$ value is 5.9418 , and its $\mathrm{P}$ value is 0.000007 , which shows that the linear relationship between the explained variables and the explanatory variables in the model is significant on the whole.

At the same time, model (1), model (2) and model (3) are established to verify the robustness of the model, and the specific results are shown in Table 3.

Table 3. Regression Results

\begin{tabular}{l|l|l|l|l}
\hline Variable & $\begin{array}{l}\text { Model (1) } \\
\text { CSR }\end{array}$ & $\begin{array}{l}\text { Model (2) } \\
\text { CSR }\end{array}$ & $\begin{array}{l}\text { Model (3) } \\
\text { CSR }\end{array}$ & $\begin{array}{l}\text { Model (4) } \\
\text { CSR }\end{array}$ \\
\hline Oversea & $\begin{array}{l}2.9955^{* * *} \\
(3.1138)\end{array}$ & $\begin{array}{l}2.4690 * * \\
(2.3585)\end{array}$ & $\begin{array}{l}2.8868^{* * *} \\
(3.1546)\end{array}$ & $\begin{array}{l}2.3573 * * \\
(2.3269)\end{array}$ \\
\hline GAV & & $\begin{array}{l}0.0133 * * * \\
(5.5733)\end{array}$ & & $\begin{array}{l}0.0131^{* * *} \\
(5.4119)\end{array}$ \\
\hline G & & & $\begin{array}{l}0.0034 * * * \\
(4.8266)\end{array}$ & $\begin{array}{l}0.0033 * * * \\
(4.9499)\end{array}$ \\
\hline $\begin{array}{l}\text { Constant } \\
\text { terms }\end{array}$ & $\begin{array}{l}22.2778^{*} * * \\
(143.3139)\end{array}$ & $\begin{array}{l}21.5132 * * * \\
(162.557)\end{array}$ & $\begin{array}{l}22.3731 * * * \\
(153.9055)\end{array}$ & $\begin{array}{l}21.6237 * * * \\
(152.0865)\end{array}$ \\
\hline $\begin{array}{l}\text { Individual } \\
\text { effect }\end{array}$ & Control & Control & Control & Control \\
\hline Sample size & 656 & 984 & 984 & 1312 \\
\hline R2 & 0.0694 & 0.0732 & 0.0793 & 0.0831 \\
\hline
\end{tabular}

Note: $* * *, * *$ and $*$ represent significance levels of $1 \%, 5 \%$ and $10 \%$ respectively (two-tailed); In brackets are the values of T statistics of robustness estimation.

As can be seen from Table 3, the regression results of random effect model show that:

(1) Overseas investment is an important explanatory variable of the model. The results show that the 
coefficient of overseas investment variable is 2.357 under the condition of keeping the gross asset value and net profit growth rate unchanged, and is significantly positive under the confidence of $5 \%$, indicating that overseas investment has a significant positive effect on corporate social responsibility, which accords with $\mathrm{H} 1$ hypothesis.

(2) The increase of gross asset value plays an obvious role in improving the total score of corporate social responsibility. Regression results show that under the condition of controlling net profit growth rate and overseas investment variables, the gross asset value coefficient is 0.0131 , which is significantly positive under the confidence of $1 \%$, that is, for every 1 million yuan increase in gross asset value, the total social responsibility score increases by 0.0131 points on average, which accords with $\mathrm{H} 2$ hypothesis.

(3) The increase of net profit growth rate can promote the total score of corporate social responsibility. Under the condition of keeping the gross asset value and the factors of overseas investment unchanged, the coefficient of net profit growth rate is 0.0033 , which is positive under the confidence of $1 \%$, that is, for every $1 \%$ increase in net profit growth rate, the total score of social responsibility increases by 0.0033 points on average, which accords with $\mathrm{H} 3$ hypothesis.

(4) In this paper, a robustness test is carried out to verify the reliability of the conclusion. By using stepwise regression method, it is confirmed that when the selected enterprises in the sample are affected by the fluctuation of enterprise scale and growth stability, the factor of overseas investment still has a significant role in promoting corporate social responsibility, and the estimation process and results of the model have certain robustness.

\section{CONCLUSIONS}

\subsection{Model enlightenment}

Based on the analysis of the random effect model, this paper draws the following two important conclusions.

Firstly, overseas investment has a positive role in promoting the social responsibility of the listed textile and garment enterprises, which promote the steady development of enterprises externally. Overseas investment can help enterprises broaden their business scope and penetrate into the world market faster; Social responsibility, as a duty and obligation that enterprises should fulfill in the process of business development, is an inevitable factor for enterprises to indirectly create profits and wealth and achieve sustainable development.

Secondly, the expansion of the scale of listed textile and garment enterprises and the enhancement of their own growth facilitate the fulfillment of corporate social responsibility, and act as the endogenous driving force for the sustainability of enterprises. The scale and growth of an enterprise, as the internal factors of an enterprise, are the main factors that directly affect the development of an enterprise. Based on the analysis of the model, it is concluded that they have a positive effect on the fulfillment of social responsibility.

\subsection{Model Conclusions}

(1) Promote overseas investment and enhance international influence. Under the opportunities and challenges brought by the Belt and Road Initiative and deglobalization, overseas investment is of great significance. However, the data show that the failure rate of overseas mergers and acquisitions of Chinese enterprises reaches above 50\%. Fundamentally, it is caused by the irrational strategy layout of the enterprise itself. Enterprises should formulate an overall strategic layout covering domestic policy research and environmental investigation of investment countries to avoid blind expansion. The industry should establish a risk assessment system for social responsibility of overseas investment, and the government should provide environmental and financial guarantee for enterprises to fulfill their social responsibility by reducing taxes and fees.

(2) Enlarge the scale of enterprises and realize economies of scale. Textile and garment enterprises should formulate efficient production factor matching mechanism and macro development plan, and adopt strategic cooperation to carry out diversified investment in order to expand their own scale. Due to the lack of industrial relevance, disassociation and serious homogenization in China's garment industry chain are becoming increasingly serious, which hinders the development of the garment industry. The textile and garment industry should gradually reshape the garment industry chain in order to enhance the connection between upstream, midstream and downstream, strengthen exchanges and cooperation, improve production efficiency through reasonable distribution, and further realize economies of scale.

(3) Attach importance to the growth of enterprises and to promote sustainable development. The research shows that the growth of enterprises is closely linked to the future development of enterprises, and its current growth degree is the key factor for enterprises to formulate development plans. Enterprises should optimize the social responsibility mechanism in many ways by improving their growth. From the perspective of employee responsibility, enterprises should follow the scientific development concept of "people-oriented" and avoid the influence of "involution" on employee enthusiasm; From the perspective of environmental responsibility, while accelerating the growth of enterprises, the government should promulgate relevant 
policies to urge enterprises and even the whole industry to strengthen environmental governance during production in order to achieve sustainable economic development.

\section{REFERENCES}

[1] Yang Liying. Analysis on the Role of Corporate Social Responsibility in Enterprise DevelopmentTaking Three Squirrels as Examples [J]. Economic Outlook the Bohai Sea, 2020, (06): 15-16.

[2] Deng Xiuyuan, Fu Chao, Fu Daiguo. An Empirical Study on the Impact of Corporate Social Responsibility on Chinese Overseas M \& As [J]. China Soft Science Magazine, 2018, (01): 110-126.

[3] Zhang Xuan, Lin Youwei, Zhang Hongxia. How Investors Evaluate Corporate Social Responsibility? An Empirical Research on China Listed Companies [J]. Chinese Journal of Management, 2019, 16 (07): 1088-1096.

[4] Cheng Yao. An Empirical Study on Financing Structure and Corporate Social Responsibility [J]. Modern Management Science, 2015, (01): 72-74.

[5] Wu Weixing, Wang Chenyu, Qu Yuanyu. A Research on Factors Affecting the Performance of Corporate Social Responsibility-From the Perspective of Listed Company Manager's Research Experience [J]. Financial Forum, 2020, 25 (05): 46-56.

[6] Zhong Peng, Wu Tao, Li Xiaoyu. An Empirical Study on the Relationship among Corporate Social Responsibility Report, Social Irresponsibility and Financial Performance of Listed Companies [J]. Forecasting, 2021, 40 (01): 17-23.

[7] Wang Quanjing. Does Overseas Investment Improve Corporate Social ResponsibilityEmpirical Test from A Dynamic Perspective [J]. Journal of International Trade, 2018, (08): 135-148.

[8] Sun Dongmei. An Empirical Study based on the Relationship between Corporate Social Responsibility and Macroeconomic Factors [J]. Social Scientists, 2018, (06): 56-62.

[9] Song Lin, Binbin, Qiao Xiaole. Research on the Influence of Institutional Distance on the Corporate Social Responsibility of Chinese Overseas Investment Firms--Moderating Effect Based on International Experience [J]. Journal of Beijing Technology and Business University (Social Sciences), 2019, 34 (02): 90-103.

[10] Yu Guansheng, Wu Qiqi, Dong Zhirang. Is the Promotion of Social Responsibility Helpful for Chinese Multinational Enterprises to Deal with
International Investment Protection? --An Empirical Study Based on the Perspective of Overseas Subsidiaries [J]. Journal of Finance and Economics, 2021, 47 (07): 154-168

[11] He Yiqing, Wan Zhen, Li Zhengtong. Corporate Liabilities, Social Responsibility and Corporate Operating Performance--Explanation Based on Scale, Assets and Ownership Structure [J]. Finance and Accounting Monthly, 2018 (06): 3-10.

[12] Guo Ying, Zhang Tingting, Xing Qian. Social Responsibility, Media Attention and Sustainable Profitability of Enterprises--Taking China's Ashare Listed Companies as an Example [J]. Hebei Enterprises, 2018 (08): 84-85.

[13] Jamali D, Karam C. Corporate social responsibility in developing countries as an emerging field of study [J]. International Journal of Management Reviews, 2018, 20(1):32-61.

[14] MIHELE C, ELEONORA A, FRANCESCO R, et al. Exploring the influence of Corporate Social Responsibility (CSR) domains on consumers loyalty: an experiment in BRICS countries [J]. Journal of Cleaner Production, 2020, 247:119158.

[15] Li Hong, Yuan Yingchao, Xu Ningning. Financial ecological environment, investor confidence, company growth and the cost of equity capital [J]. Finance and Accounting Newsletter, 2018, (03): 49-54. DOI: $10.16144 /$ j. cnki issn10028072.2018.03.011.

[16] Yang Liu. Enterprise scale, market competition and total factor productivity of military enterprises [D]. Xiangtan University, 2019: 